\title{
Bone Scan with Confusing Appearance: Superscan or Metabolic Disorder
}

\author{
Stefan Gratz ${ }^{*}, 1,2$, Wolf Kaiser ${ }^{2}$ and Thomas M. Behr ${ }^{1}$ \\ ${ }^{I}$ Department of Nuclear Medicine of the Philipps University, Marburg, Germany \\ ${ }^{2}$ Department of Nuclear Medicine, Stuttgart, Germany
}

\begin{abstract}
We present a patient with metastatic prostate cancer with known bone involvement and unknown osteomyelofibrosis. It has the general appearance of a superscan, with homogeneously increased tracer uptake and no visualization of the kidneys. However, while a superscan should have greater uptake in the axial skeleton compared to the appendicular skeleton, this scan is reverse, raising the suspicion of an overlying metabolic bone disorder. Subsequent laboratory-, bioptical findings confirmed a myeloproliferative syndrome with osteomyelofibrosis. As such, this scan demonstrates that in a patient with both affiliations, metabolic bone disease can override even severe osseous metastases on a bone scan.
\end{abstract}

Keywords: Prostate cancer, metastasis, metabolic disorder, bone scan.

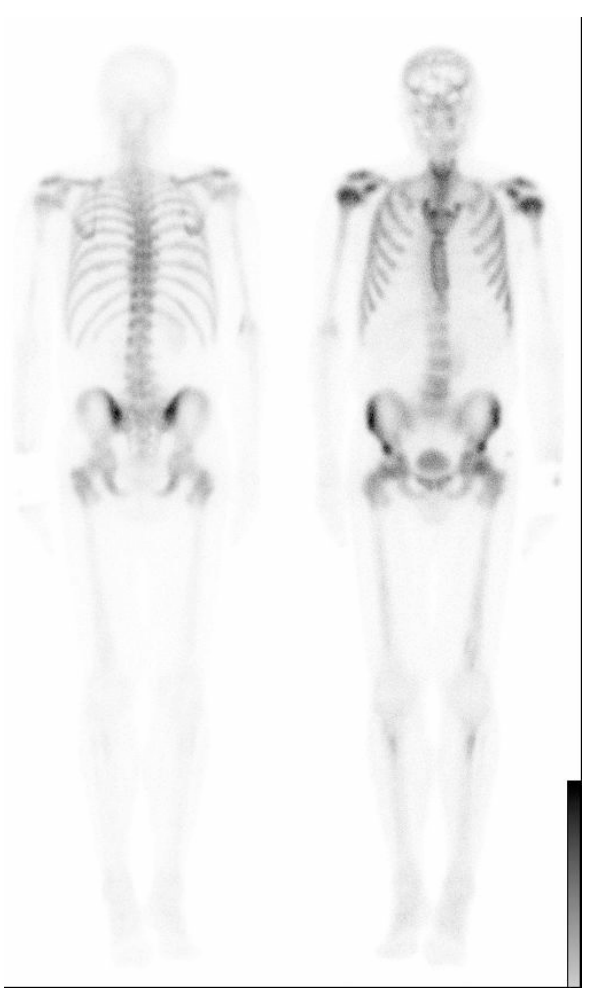

Fig. (1). An-65-year old man had history of metastatic prostate carcinoma and known bone involvement. In the past, prior to the prostate carcinoma the patient had suffered from leukocytopenia and thrombocythaemia. A histological evaluation (method of Gomori [1]: semiquantitatively using reticulin fiber impregnation) of the bone marrow biopsy did not demonstrate any fibrotic changes involving bone marrow. Nevertheless a low dose anagrelide therapy was started [2, 3], a drug which selectively reduces the platelet counts and which is known to be of efficacious control of thrombocytosis. Furthermore, an increase of the size and consistency of the spleen was also known. Due to ongoing discomfort, weakness, loss of weight and increase of PAS level from $12.2 \mathrm{ng} / \mathrm{ml}$ to $19.6 \mathrm{ng} / \mathrm{ml}$ within the last $3 \mathrm{months}$ the patient was sent for bone scanning because of suspected progressive metastatic bone involvement. The first impression of the bone scan was a superscan, especially because of the fact that the kidneys were not shown. While the typical heterogeneous appearance of metastases normally is distinct from homogeneous uptake in metabolic bone disease, the appearance of confluent disease (a superscan) can be quite similar as seen in the present patient [4-7]. A repeated bone marrow biopsy and MRI finally led to the diagnosis of osteomyelofibrosis.

*Address correspondence to this author at the Department of Nuclear Medicine, Seelbergstraße 11, D-70372 Stuttgart, Germany;

Tel: 011 - 49 - 711-5538241; Fax: 011 - 49 - 711-5538246;

E-mail: Nuklearmedizin-Gratz@gmx.net 


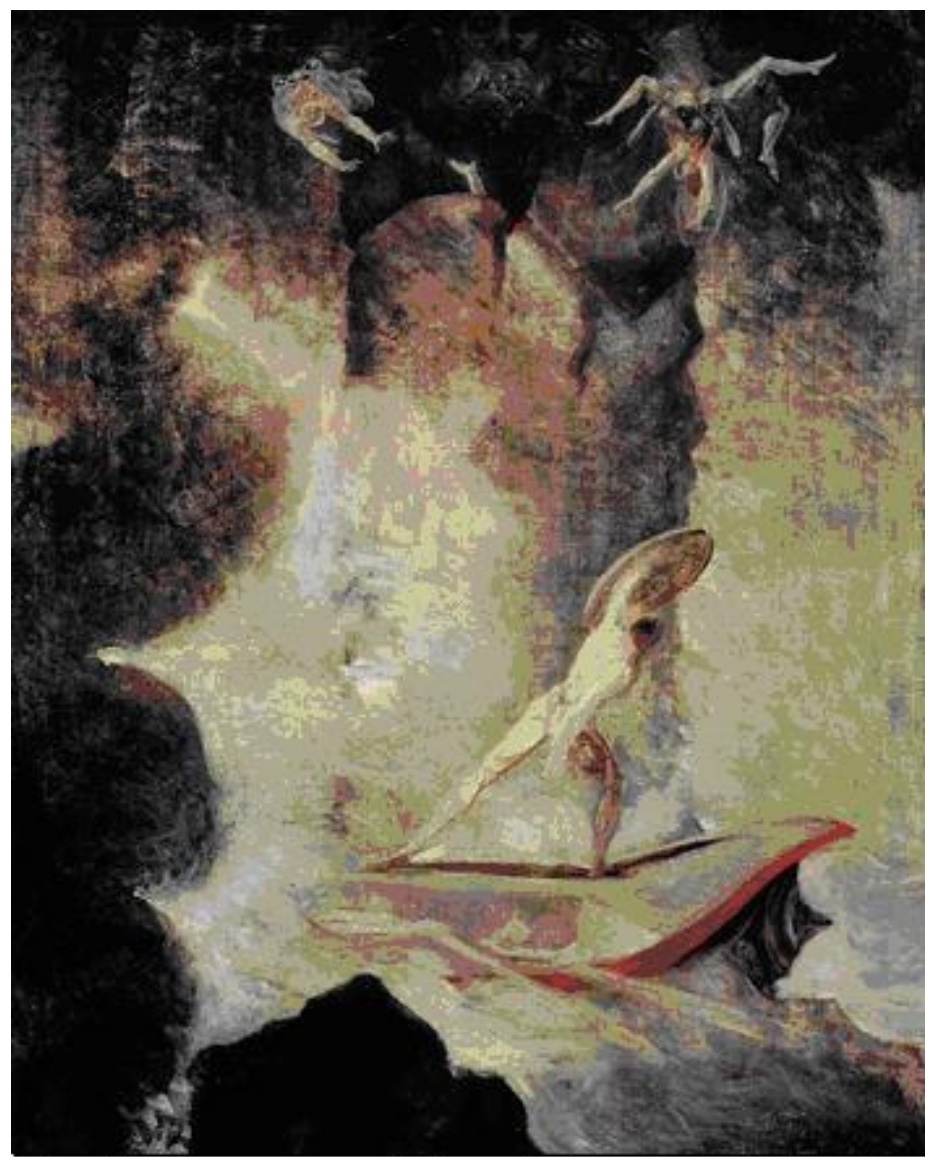

Fig. (2). As with Scylla and Charybdis [8], two sea monsters of Greek mythology situated on opposite sides of a narrow channel of water, a physician reading this bone scan has to choose between two unattractive choices.

\section{REFERENCES}

[1] Adamkov M, Plank L, Szépe P. Occurrence of myelofibrosis in individual types of chronic myeloproliferative diseases.Bratisl Lek Listy 1998; 99: 240-4.

[2] Trapp OM, Beykirch MK, Petrides PE. Anagrelide for treatment of patients with chronic myelogenous leukemia and a high platelet count. Blood Cells Mol Dis 1998; 24: 9-13.

[3] Thiele J, Chen YS, Kvasnicka HM, Diehl V, Fischer R. Evolution of fibro-osteosclerotic bone marrow lesions in primary (idiopathic) osteomyelofibrosis--a histomorphometric study on sequential trephine biopsies. Leuk Lymphoma 1994; 14: 163-9.
[4] Hain SF, Fogelman I. Nuclear medicine studies in metabolic bone disease. Semin Muskuloskelet Radiol 2002; 6: 323-29.

[5] Ziessman HA, O'Malley JP, Thrall JH. Nuclear medicine, $3^{\text {rd }}$ ed. Philadelphia, PA: Elsevier; 2006.

[6] Ryan PJ. Orthopaedic manifestations of systemic disease. Semin Nucl Med 1998; 28: 124-31.

[7] Oyen WJ, Raemaekers JM, Corstens FH. Acute myelofibrosis mimicking multiple bone metastases on Tc-99m MDP bone imaging. Clin Nucl Med 1998; 23: 1-2.

[8] Henry Fuseli (in German, Johann Heinrich Füssli; February 7, 1741 - April 16, 1825) was a British painter, draughtsman, and writer on art, of German-Swiss origin.

(C) Gratz et al.; Licensee Bentham Open.

This is an open access article licensed under the terms of the Creative Commons Attribution Non-Commercial License (http://creativecommons.org/licenses/by$\mathrm{nc} / 3.0 /$ ) which permits unrestricted, non-commercial use, distribution and reproduction in any medium, provided the work is properly cited. 